\title{
Article \\ Tie-2, G-CSF, and Leptin as Promising Diagnostic Biomarkers for Endometrial Cancer: A Pilot Study
}

\author{
Luka Roškar $^{1}\left(\mathbb{D}\right.$, Teja Klančič ${ }^{2}$, Tamara Knific ${ }^{2}$, Tea Lanišnik Rižner ${ }^{2, * \mathbb{D}}$ and Špela Smrkolj ${ }^{1,3}$ (D) \\ 1 Department of Obstetrics and Gynaecology, Faculty of Medicine, University of Ljubljana, \\ 1000 Ljubljana, Slovenia; luka.roskar@outlook.com (L.R.); spela.smrkolj@mf.uni-lj.si (̌̌.S.) \\ 2 Institute of Biochemistry, Faculty of Medicine, University of Ljubljana, 1000 Ljubljana, Slovenia; \\ teja.klancic@mf.uni-lj.si (T.K.); tamara.knific@mf.uni-lj.si (T.K.) \\ 3 Department of Obstetrics and Gynaecology, University Medical Centre, 1000 Ljubljana, Slovenia \\ * Correspondence: tea.lanisnik-rizner@mf.uni-lj.si; Tel.: +386-0-1543-7657
}

check for

updates

Citation: Roškar, L.; Klančič, T.; Knific, T.; Rižner, T.L.; Smrkolj, Š. Tie-2, G-CSF, and Leptin as Promising Diagnostic Biomarkers for Endometrial Cancer: A Pilot Study. J. Clin. Med. 2021, 10, 765. https:// doi.org/10.3390/jcm10040765

Academic Editor: Andrea Romano Received: 4 November 2020

Accepted: 3 February 2021

Published: 15 February 2021

Publisher's Note: MDPI stays neutral with regard to jurisdictional claims in published maps and institutional affiliations.

Copyright: (C) 2021 by the authors. Licensee MDPI, Basel, Switzerland. This article is an open access article distributed under the terms and conditions of the Creative Commons Attribution (CC BY) license (https:// creativecommons.org/licenses/by/ $4.0 /)$.

\begin{abstract}
Preoperative determination of the extent of endometrial cancer (EC) would avoid the complications associated with radical surgery. Screening of patients' plasma biomarkers might enable a more precise diagnosis of EC and a tailored treatment approach. This prospective case-control monocentric pilot study included 76 postmenopausal women (38 endometrioid EC patients and 38 control patients with benign gynecological conditions), and 37 angiogenic factors (AFs) were investigated as potential biomarkers for EC. AF concentrations in preoperative plasma samples were measured using Luminex xMAP ${ }^{\mathrm{TM}}$ multiplexing technology. The plasma levels of sTie- 2 and G-CSF were significantly lower in EC compared to control patients, whereas the plasma levels of leptin were significantly higher in EC patients. Neuropilin-1 plasma levels were significantly higher in patients with type $2 \mathrm{EC}$ (grade 3) compared to patients with lower grade cancer or controls. Follistatin levels were significantly higher in patients with lymphovascular invasion, and IL-8 plasma levels were significantly higher in patients with metastases. If validated, the plasma concentrations of the indicated AFs could represent an important additional diagnostic tool for the early detection and characterization of EC. This could guide the decision-making on the extent of surgery. Further studies with larger patient numbers are currently ongoing.
\end{abstract}

Keywords: biomarkers; angiogenesis; endometrial cancer; angiogenic factors; Tie-2; G-CSF; leptin

\section{Introduction}

Endometrial cancer (EC) is a leading gynecological malignancy in the developed world and its incidence is rapidly increasing [1,2]. Classification according to endocrine and metabolic disturbances divides endometrial cancer into two types. Well- or moderately differentiated endometrioid EC represents prognostically favorable type 1 EC, whereas poorly differentiated endometrioid EC represents prognostically less favorable type 2 EC with a tendency for deep myometrial invasion (DMI) and metastasis [3-5]. The average 5-year overall survival rates are $85.6 \%$ and 58.8\% for type 1 and 2 EC, respectively [4].

While this classification into two types is still widely in use, a newer molecular classification according to genomic, transcriptomic, and proteomic characterizations was proposed in 2014, dividing EC into four categories and offering a more tailored therapeutic approach [6]. Recently it has been demonstrated that the integration of molecular profiling into a daily routine is possible and is expected to change treatment decisions [7]. Nevertheless, the diagnosis and treatment strategy for EC are still mostly defined according to the histological findings of endometrial biopsies [8]. The most important histological findings, which determine the extension of further surgical therapy, are the type and grade of EC as well as the presence of DMI or lymphovascular invasion (LVI) [9,10]. In terms of histopathology, endometrioid EC is categorized as being well differentiated (G1), moderately differentiated (G2), and poorly differentiated (G3) [11]. 
Frequently, the histological findings from biopsies do not correlate with the histological findings after hysterectomy, and thus additional methods are needed to more precisely determine the extent of the disease [12-14]. Plasma biomarkers represent very important diagnostic, therapeutic, and prognostic tools for the treatment of different malignancies. Despite the frequency of EC versus other malignancies, there is currently still no biochemical screening with diagnostic or prognostic markers, other than CA-125 and HE4, available in clinical practice $[9,15]$. The discovery of new plasma biomarkers would enable a more precise diagnosis of EC and a tailored treatment approach [16].

One group of potential biomarkers are angiogenic factors (AFs) that comprise relatively small molecules, usually cytokines or chemokines, the production of which is influenced by cancerous tissue $[17,18]$. AFs include both proangiogenic factors like VEGF, and inhibitors of angiogenesis like angiostatin. In cancer cells, production of AF is dysregulated to enable the faster sprouting of new vessels (Figure 1) [19]. The main trigger that influences AF production is the lack of oxygen that occurs due to insufficient diffusion when cancerous tissue is located $0.1-0.2 \mathrm{~mm}$ from the blood vessels $[18,20]$. At this stage, AFs transform the surrounding vascular tissue into a supply network that enables the fast growth, spread, and metastasis of cancer [21]. The production of AFs by cancer cells leads to altered AF levels in the surrounding tissue and blood plasma [22,23]. Altered AF levels may thus represent potential markers, which could detect cancer from blood plasma samples in the early and prognostically favorable stages of cancer [24]. The plasma concentrations of AFs could also represent an important additional diagnostic tool for a more precise diagnosis of EC; this could guide decision-making regarding the extent of surgery. This could be limited to hysterectomy and bilateral adnexectomy or could even be extended to the more radical procedure in which also pelvic and para-aortic lymphadenectomy is performed. These extended procedures have a higher rate of possible complications and postoperative morbidity, such as permanent lymphedema, ascites, or nerve damage $[15,25,26]$.

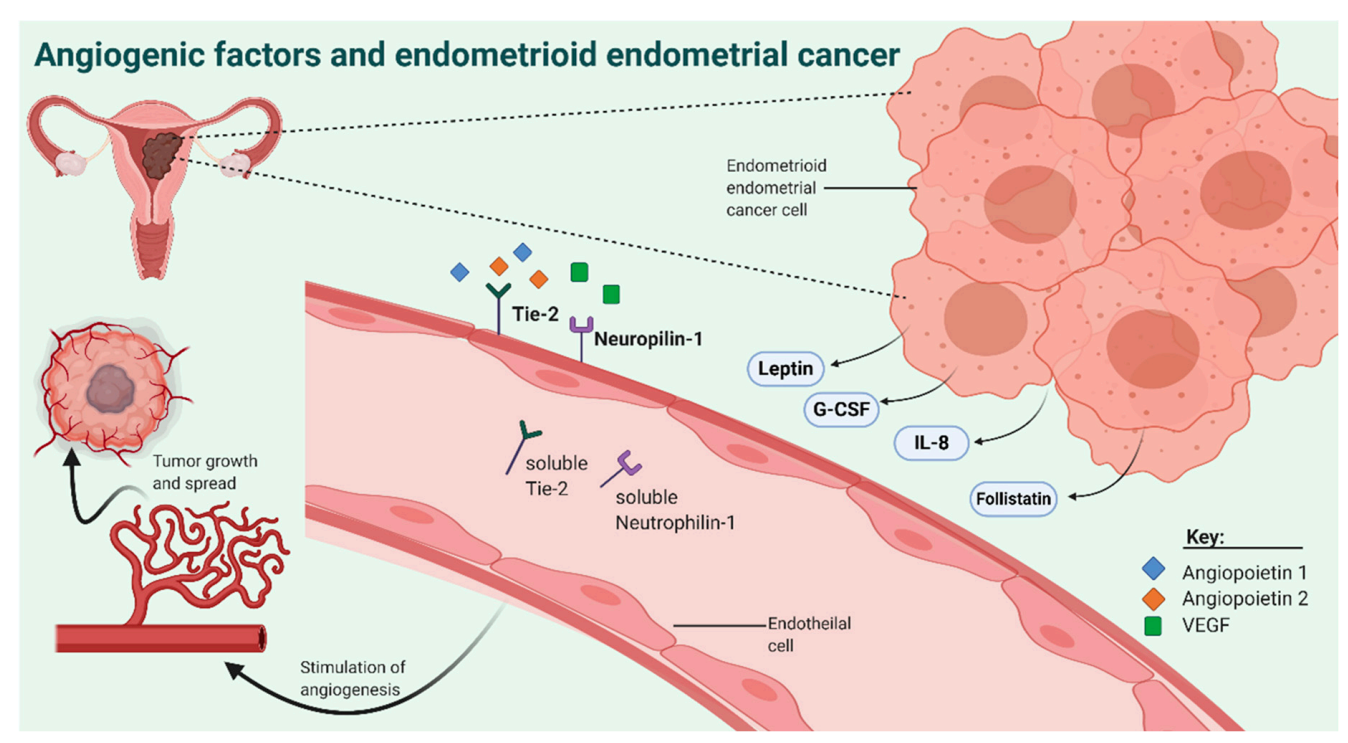

Figure 1. The angiogenic factors involved in the pathology of endometrioid EC. Created with BioRender.com.

In the present study, we evaluated the concentrations of 37 different AFs in preoperative plasma samples of patients with endometrioid EC and control patients with benign gynecological conditions (e.g., prolapsed uterus or chronic pelvic pain). 


\section{Experimental Section}

\subsection{Patient Enrolment}

Patient enrolment took place at the Department of Obstetrics and Gynecology, University Medical Centre Ljubljana, Slovenia. In this monocentric case-control study, we included 76 women who underwent surgical treatment, including a group of EC patients $(n=38)$ and a control group of women with prolapsed uteri or myoma $(n=38)$. Women were excluded from the study if they were of reproductive age or had other non-endometrioid EC malignancies, HIV infection, or acute inflammation. This study was approved by the National Medical Ethics Committee of the Republic of Slovenia (No. 0120-515/2017/4), and all participants signed written informed consent before participating in this study.

The patients were recruited by senior gynecologists with the help of study nurses. One day to one week prior to surgery, morning blood samples were collected, and additional information was obtained regarding lifestyle, medication used, and gynecological and clinical status (Table 1 and Supplementary Tables S1 and S2). For sample collection and processing, strict and detailed standard operating procedures were followed, and plasma samples were stored at $-80^{\circ} \mathrm{C}$ until further analysis.

Table 1. Detailed clinical characteristics of the study participants.

\begin{tabular}{|c|c|c|c|c|}
\hline & & $\begin{array}{c}\text { Control Patients } \\
n=38(100 \%)\end{array}$ & $\begin{array}{c}\text { EC Patients } \\
n=38(100 \%)\end{array}$ & $\begin{array}{c}p^{\mathrm{a}} \\
\text { Values }\end{array}$ \\
\hline \multirow[t]{4}{*}{ Age category } & $50-59.9$ years & $10(26.3)$ & $11(28.9)$ & \multirow{4}{*}{ ns } \\
\hline & $60-69.9$ years & $12(31.6)$ & $14(36.8)$ & \\
\hline & $70-79.9$ years & $15(39.5)$ & $12(31.6)$ & \\
\hline & $>80$ years & $1(2.6)$ & $1(2.6)$ & \\
\hline \multirow[t]{6}{*}{$\begin{array}{l}\text { Body mass index } \\
\qquad\left(\mathrm{kg} / \mathrm{m}^{2}\right)\end{array}$} & 18.6-24.9 (normal weight) & $10(26.3)$ & $4(10.5)$ & \multirow{6}{*}{0.001} \\
\hline & 25-29.9 (overweight) & $16(42.1)$ & $15(39.5)$ & \\
\hline & 30-34.9 (class I obesity) & $6(15.8)$ & $9(23.7)$ & \\
\hline & 35-39.9 (class II obesity) & $1(2.6)$ & $6(15.8)$ & \\
\hline & 40-49.9 (class III obesity) & $0(0)$ & $4(10.5)$ & \\
\hline & Missing data & $5(13.2)$ & $0(0)$ & \\
\hline \multirow[t]{5}{*}{ Smoking status } & Nonsmoker & $29(76.3)$ & $30(78.9)$ & \multirow{5}{*}{ ns } \\
\hline & Smoker & $2(5.3)$ & $3(7.9)$ & \\
\hline & Occasional smoker & $2(5.3)$ & $2(5.3)$ & \\
\hline & Former smoker & $3(7.9)$ & $3(7.9)$ & \\
\hline & Missing data & $2(5.3)$ & $0(0)$ & \\
\hline \multirow{3}{*}{$\begin{array}{l}\text { Hormonal } \\
\text { therapy in the } \\
\text { past }\end{array}$} & No & $21(55.3)$ & $25(65.8)$ & \multirow{3}{*}{ ns } \\
\hline & Yes & $3(7.9)$ & $1(2.6)$ & \\
\hline & Missing & $14(36.8)$ & $12(31.6)$ & \\
\hline \multirow{3}{*}{$\begin{array}{c}\text { Peroral } \\
\text { contraception in } \\
\text { the past }\end{array}$} & No & $18(47.4)$ & $16(42.1)$ & \multirow{3}{*}{ ns } \\
\hline & Yes & $7(18.4)$ & $7(18.4)$ & \\
\hline & Missing & $13(34.2)$ & $15(39.5)$ & \\
\hline \multirow{3}{*}{$\begin{array}{c}\text { Medication } \\
\text { intake in last } 7 \\
\text { days }\end{array}$} & No & $0(0)$ & $1(2.6)$ & \multirow{3}{*}{ ns } \\
\hline & Yes & $33(86.8)$ & 28 (73.7) & \\
\hline & Missing data & $5(13.2)$ & $9(23.7)$ & \\
\hline
\end{tabular}

a $p$ values were calculated using the non-parametric Mann-Whitney test for continuous variables and the chi-squared test for categorical variables; ns $=$ not significant. 


\subsection{Measurements of AFs}

All plasma samples were tested for 37 circulating angiogenesis biomarkers using Luminex xMAP multiplexing technology with two Milliplex ${ }^{\circledR}$ MAP Human Angiogenesis/Growth Factor Magnetic Bead Panels: 20-plex HANG2MAG-12K and 17-plex HAGP1M AG-12K (Merck Millipore, Burlington, Massachusetts, USA, LOT\#HAGP2-8012-2 and LOT\#3282193, respectively). All tests were performed according to the manufacturer's protocol. Limit of detection (LOD) for 37 angiogenesis biomarkers are included in Supplementary Table S3. Briefly, the method is based on $5.5 \mu \mathrm{m}$ polystyrene beads that are labelled with two different fluorescent dyes at different ratios assigned for each individual antibody, thus enabling the quantification of 37 different angiogenesis biomarkers (Table 2). The samples were anonymized, and the person performing the assays was blind to the identity of the samples. xPonent 4.2 Software, Luminex, Austin, Texas, USA, with five-parameter logistic regression modelling was used to calculate the final concentrations.

Table 2. Plasma concentrations $(\mathrm{pg} / \mathrm{mL})$ of the measured angiogenesis biomarkers.

\begin{tabular}{|c|c|c|c|c|c|}
\hline & \multicolumn{2}{|c|}{ Control Patients $n=38$} & \multicolumn{2}{|c|}{ EC Patients $n=38$} & \multirow[t]{2}{*}{$p^{\mathrm{a}}$ Values $(<0.05)$} \\
\hline & Median & Range & Median & Range & \\
\hline angiostatin & $68,762.7$ & $26,019.6-131,674.6$ & $68,968.4$ & $10,337.8-133,835.1$ & \\
\hline sAXL & 1352.0 & $447.3-2214.6$ & 1400.2 & 487.3-1932.0 & \\
\hline sc-Kit/SCFR & $25,473.2$ & $6497.9-44,838.5$ & $27,755.8$ & $6382.0-47,182.2$ & \\
\hline sHer2 & 4686.2 & $2750.8-6958.6$ & 4589.5 & $2247.6-7616.4$ & \\
\hline sHer3 & 5310.9 & $735.3-7160.7$ & 4921.2 & 2174.1-8658.4 & \\
\hline sE-Selectin & $88,127.2$ & $42,351.2-164,728.6$ & $84,245.3$ & $35,178.1-132,759.8$ & \\
\hline sHGFR/c-Met & $39,388.4$ & $12,640.9-86,504.3$ & $38,925.6$ & $22,210.5-74,766.1$ & \\
\hline Tenascin C & $11,069.2$ & $1242.1-22,237.3$ & $10,313.6$ & $1179.9-18,276.6$ & \\
\hline PDGF-AB/BB & 921.7 & $266.2-2355.9$ & 914.4 & 338.5-9049.4 & \\
\hline sIL-6Ralpha & $26,213.5$ & $8505.9-40,310.4$ & $27,467.1$ & $5581.6-42,348.2$ & \\
\hline sTie-2 & 9862.9 & $2465.8-16,502.5$ & 8191.4 & $5314.6-13,762.4$ & 0.0218 \\
\hline Thrombospondin-2 & 8696.5 & $1347.0-26,885.0$ & 7591.7 & $910.6-18,021.5$ & \\
\hline sNeuropilin-1 & $387,531.5$ & $55,935.1-916,924.7$ & $459,548.5$ & $81,804.2-775,122.2$ & \\
\hline sEGFR & 1157.7 & 321.9-1949.8 & 1212.5 & 386.9-2136.5 & \\
\hline SUPAR & 9886.1 & $3055.3-18,468.5$ & $10,253.5$ & $4365.7-16,059.8$ & \\
\hline sVEGFR1 & 1049.8 & $114.8-2381.0$ & 979.1 & $142.4-2116.0$ & \\
\hline sVEGFR3 & $14,534.9$ & $1908.7-28,017.4$ & $12,534.2$ & $546.7-26,452.6$ & \\
\hline sPECAM-1 & 5301.3 & $1907.4-7014.2$ & 4814.0 & $1364.5-7573.7$ & \\
\hline Osteopontin & 4620.1 & $1745.7-9509.6$ & 4037.6 & 1721.5-9583.0 & \\
\hline sVEGFR2 & $12,044.6$ & $6781.0-17,613.6$ & $12,520.4$ & $6115.8-18,684.0$ & \\
\hline Angiopoietin-2 & 2442.0 & $594.3-7937.8$ & 2209.4 & $733.3-5191.5$ & \\
\hline BMP-9 & 103.2 & $7.9-244.7$ & 110.1 & $19.2-847.6$ & \\
\hline Endoglin & 1741.2 & $589.4-3370.5$ & 1730.9 & $364.4-2808.5$ & \\
\hline Follistatin & 1054.8 & 190.3-1901.1 & 1032.3 & $153.4-2692.5$ & \\
\hline G-CSF & $214.8^{c}$ & $29.0-578.6$ & $158.1^{\mathrm{c}}$ & $16.8-384.3$ & 0.0175 \\
\hline HB-EGF & 40.9 & $2.8-169.3$ & 32.4 & $8.0-153.0$ & \\
\hline HGF & 221.1 & $127.8-458.6$ & 277.2 & $93.4-589.1$ & \\
\hline Leptin & $40,208.9$ & $12,646.1-12,7802.3$ & $50,185.7$ & $10,869.2-240,758.2$ & 0.0451 \\
\hline VEGF-C & 911.7 & $350.6-3110.3$ & 881.6 & $169.4-2508.0$ & \\
\hline VEGF-D & 151.9 & $3.7-481.9$ & 150.1 & $27.4-469.8$ & \\
\hline EGF & $21.8^{\mathrm{d}}$ & $1.5-119.1$ & $21.8^{\mathrm{d}}$ & $1.1-70.4$ & \\
\hline Endothelin-1 b & - & - & - & - & \\
\hline FGF-1 ${ }^{b}$ & - & - & - & - & \\
\hline FGF-2 & 120.4 & $65.8-240.7$ & 120.4 & $65.8-240.7$ & \\
\hline IL-8 & 4.2 & $0.6-21.2$ & 4.4 & $1.7-14.3$ & \\
\hline PLGF & 8.6 & $1.8-36.9$ & 7.1 & $1.8-265.8$ & \\
\hline VEGF-A & 67.4 & $6.8-771.8$ & 77.9 & $6.8-225.2$ & \\
\hline
\end{tabular}

${ }^{a} p$ values were calculated using the non-parametric Mann-Whitney test; values below 0.05 were considered statistically significant; ${ }^{\mathrm{b}}$ below the detection limit; ${ }^{\mathrm{c}} \mathrm{EC}$ patients: $\mathrm{n}=38$, control patients: $\mathrm{n}=37$, one measurement was below the detection limit; ${ }^{\mathrm{d}} \mathrm{EC}$ patients: $\mathrm{n}=30$, control patients: $\mathrm{n}=34$, other measurements were below the detection limit. 
The same plasma samples were previously analyzed using electrochemiluminescent immunoassays specific for CA-125 and HE4 on a Cobas e411 immunoassay analyzer (Roche Diagnostics GmbH, Manheim, Germany). Quantitative detection kits for CA-125 (REF: 11776223190, LOT: 139788-01) and HE4 (REF: 05950929190, LOT: 112732-01) were used [27].

\subsection{Statistics}

The differences in plasma AF levels between EC patients and control patients were analyzed, as were the differences between EC patients with or without lymphovascular invasion and deep myometrial invasion, EC patients with different grades of the disease, and EC patients with or without metastasis.

The Shapiro-Wilk test was used to determine the normality of the distributions and as the data were not normally distributed the two-sided Mann-Whitney $U$ test was used for univariate statistical analysis of differences between EC patients and control patients. The non-parametric Kruskal-Wallis test with Dunn's multiple comparison corrections as post-hoc tests was used to compare more than two groups. The chi-square test was used to compare categorical variables. The results of the descriptive analysis (i.e., the patient's clinical data) were presented as mean \pm standard deviation, while the concentrations of the measured proteins were presented as median and range (Table 2). Statistical significance was set at $p<0.05$. Receiver operating characteristic (ROC) curves for the angiogenic biomarkers CA-125 and HE4 were used to compare the separation between EC and control patients.

\section{Results}

\subsection{Characteristics of the EC Patients and Control Patients}

The case group comprised 38 EC patients with a mean age of $65.9 \pm 8.2$ years (range: $52-88$ years) and mean body mass index (BMI) of $31.8 \pm 6.1 \mathrm{~kg} / \mathrm{m}^{2}$ (range: $20.6-45.7 \mathrm{~kg} / \mathrm{m}^{2}$ ). The detailed clinical characteristics are presented in Table 1 and in Supplementary Table S1.

LVI was observed in 5 patients (13.2\%), DMI in 12 patients (31.6\%), <50\% invasion into the myometrium in 15 patients (39.5\%), and no invasion into the myometrium in 11 patients $(28.9 \%)$. According to the classification of the International Federation of Gynecology and Obstetrics [28], the following EC stages were observed: IA ( $n=23,60.5 \%)$, IB $(n=9,23.7 \%)$, IIIA $(n=2,5.3 \%)$, IIIB $(n=1,2.6 \%)$, and IIIC $(n=3,7.9 \%)$.

The control group included 38 patients with a mean age of $66.9 \pm 8.4$ years (range: $52-83$ years) and mean BMI of $27.5 \pm 3.9 \mathrm{~kg} / \mathrm{m}^{2}$ (range: $21.6-38.7 \mathrm{~kg} / \mathrm{m}^{2}$ ). The detailed clinical characteristics are presented in Table 1 and Supplementary Table S1.

When both groups were compared, there was a statistically significant difference in BMI $(p=0.001)$; however, there were no differences in age distribution, hormonal therapy, medication intake, or smoking status (Table 1 and Supplementary Tables S1 and S2). None of the included patients received drugs with known anti-angiogenic effect and no neoadjuvant chemotherapy was used.

\subsection{Levels of AFs in EC and Control Patients}

All 37 AFs were measured in all plasma samples. Univariate statistical analysis revealed statistically significant differences in the plasma concentrations of three AFs between EC and control patients (Table 2, Figure 2). The plasma levels of sTie-2 and G-CSF were significantly decreased in EC patients compared to those of control patients $(p<0.05)$. Within the EC group, Tie-2 levels were lower in patients with LVI and DMI; however, these differences did not reach statistical significance. Additionally, G-CSF levels were insignificantly lower in patients with DMI. 


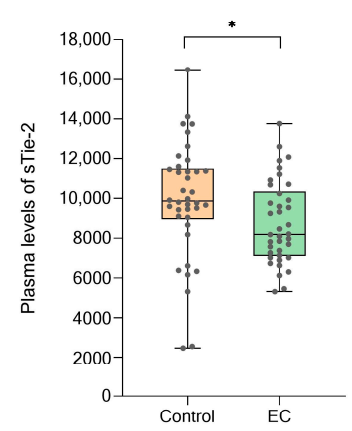

$E$

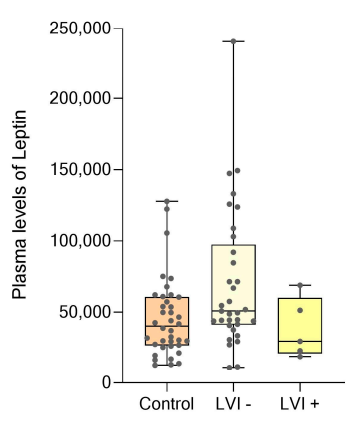

B

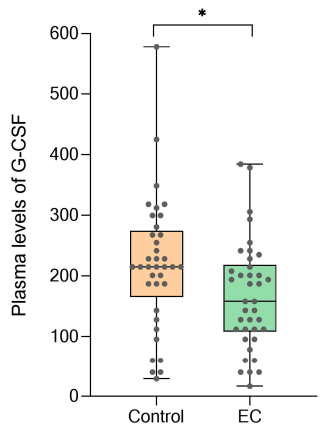

$\mathrm{F}$

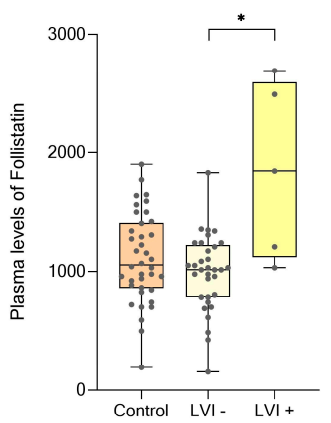

C

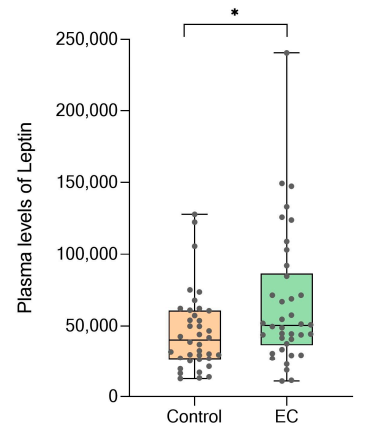

G

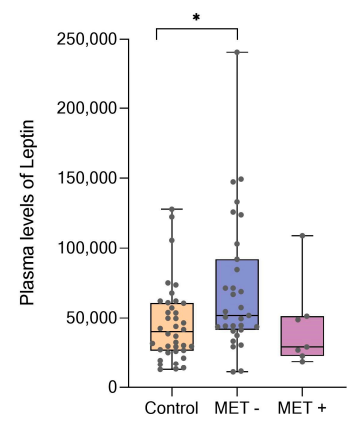

D

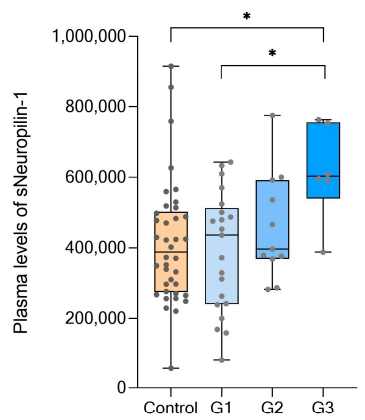

$\mathrm{H}$

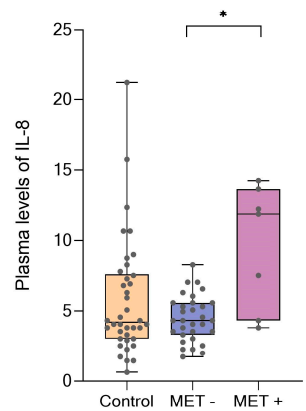

Figure 2. Box plots (min to max with all points shown) comparing plasma levels of angiogenic biomarkers (pg/mL) between study groups. (A-C) Control and endometrial cancer (EC) patients. (D) Control patients and patients with different grades of EC. (E,F) Control patients and patients with or without lymphovascular invasion (LVI). (G,H) Control patients and patients with or without metastasis (MET). ${ }^{*}$ signifies $p<0.05$.

Leptin levels were significantly elevated in EC versus control patients, and the difference was most distinguished, although not significant, in patients with poorly differentiated, grade 3 tumors. Similarly, neuropilin-1 levels were significantly higher in patients with grade 3 cancer than in patients with lower grade cancer or controls $(p<0.05)$.

Leptin levels were insignificantly elevated in patients with locally limited disease without LVI, yet decreased in patients with disseminated disease with LVI. This is probably due to the higher BMI of patients without LVI (the mean BMI values were $32.1 \mathrm{~kg} / \mathrm{m}^{2}$ and $29.9 \mathrm{~kg} / \mathrm{m}^{2}$ in patients without and with LVI, respectively), as leptin is known to be increased in more obese patients [29]. Interestingly, follistatin levels were significantly higher in patients with LVI, and IL-8 levels were significantly higher in patients with metastasis (Figure 2). However, these findings should be considered with caution and confirmed in a larger group of patients, as our cohort only included five patients with LVI and seven patients with metastases.

The diagnostic characteristics of three AFs with detected differences in plasma levels between EC and control patients were compared to those of CA-125 and HE4, previously measured in our lab [27]. ROC curve analysis revealed a slightly lower area under the curve (AUC) values for three AFs compared to those of CA-125 and HE4. The highest AUC value of 0.65 was determined for Tie-2, followed by 0.64 and 0.63 for G-CSF and leptin, respectively (Figure 3). 


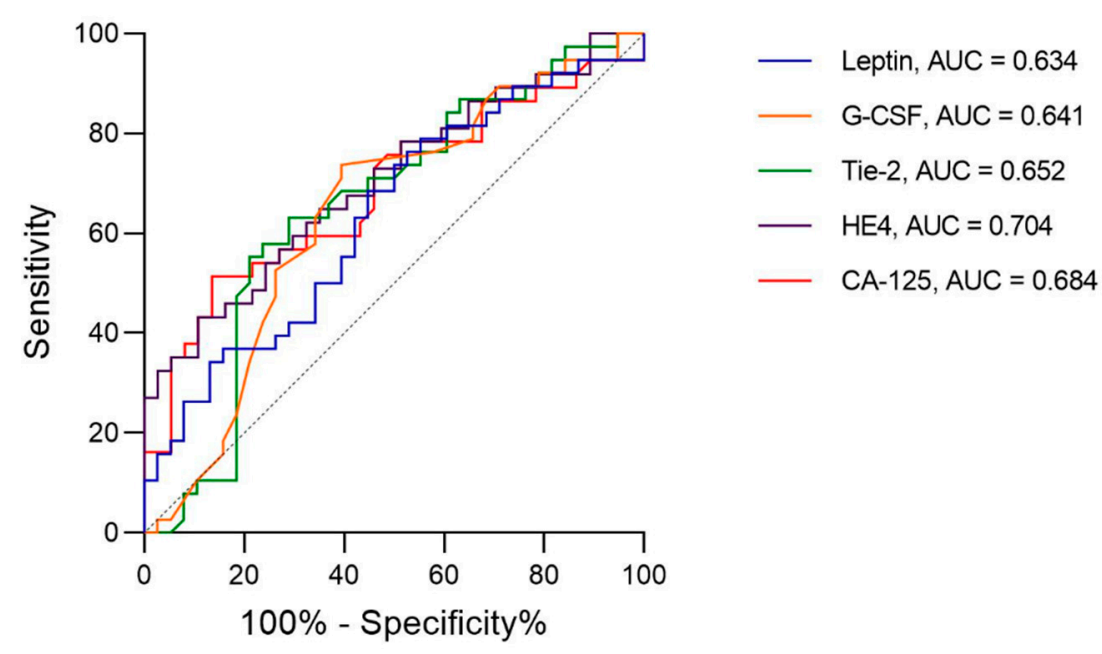

Figure 3. Diagnostic receiver operating characteristic (ROC) curves with area under the curve (AUC) values for three angiogenic biomarkers compared to CA-125 and HE-3.

\section{Discussion}

Increased levels of pro-angiogenic factors were previously demonstrated in EC tissue by immunohistochemistry [30]. However, a clinically less invasive and faster approach to detect increased angiogenesis is to examine plasma levels of AFs. Unlike immunohistochemical analyses, analyses of plasma AFs in EC patients have rarely been performed [3]. Our study has demonstrated differences in the plasma levels of Tie-2, G-CSF, and leptin between EC and control patients. Appropriate validation and studies on larger groups of patients may reveal that these proteins have the potential to be included into diagnostic models, which could lead to earlier and more tailored EC therapy in the future.

Our study also showed increased plasma levels of IL-8 in metastatic cases of endometrioid EC, which is in accordance with a previous in vitro study on cell lines [31]. Currently, EC staging is mainly assessed by histological examination of pelvic and paraaortic nodules that are obtained by lymphadenectomy [9]. Therefore, plasma levels of IL-8 in EC patients should be further evaluated as a staging tool that could present a less invasive alternative to the current lymphadenectomy.

The cytokine VEGF has been proven as an important AF in different types of cancer [32,33]. Its ability to increase vessel permeability and endothelial proliferation as well as its antiapoptotic effect make it the most researched AF and potential target for anticancer targeted therapy [34,35]. However, due to cyclic proliferation, endometrial tissue undergoes a repetitive physiological process of angiogenesis every month. Studies have demonstrated different tissue levels of VEGF between the proliferative and secretory phase [36,37]. To exclude the impact of cyclic steroid hormone levels on angiogenesis, our study included only postmenopausal women.

Previous immunohistochemical studies are inconclusive about the importance of VEGF in EC tissue. While some animal models also showed the importance of VEGF in EC [19,38], other studies did not observe higher VEGF levels in EC tissue [36,39]. However, Shaarawy and El-Sharkawy reported higher VEGF levels in serum from patients with endometrial hyperplasia and endometrial cancer in the comparison to the control group of postmenopausal women. They also observed significantly decreased VEGF levels after treatment [40]. In our study, we did not detect differences in VEGF plasma levels between EC and control patients. Nonetheless, the levels of neuropilin-1, an essential co-receptor for VEGF, were increased in poorly differentiated (G3) EC patients. This is in accordance with the immunohistochemical study by Okon et al. [41], which demonstrated that atypical neuropilin-1 expression in endometrial tissue may serve as a biomarker for metastatic endometrial tumors. Another study demonstrated that neuropilin-1 was 
exclusively present in cancer cells, as opposed to the control samples, and at distinctly higher levels in G2 and G3 than those in G1 [42].

Our results indicate that follistatin levels are elevated in EC patients with LVI. To the best of our knowledge, follistatin has not been previously analyzed in blood samples from EC patients. However, one study demonstrated higher serum follistatin levels in ovarian cancer patients compared to patients with benign ovarian cysts [43]. At the mRNA level there were no significant differences in expression of follistatin when comparing atrophic endometrial tissue to adenocarcinoma tissue [44]. However, The Cancer Genome Atlas (TCGA) data indicate that EC patients with higher follistatin mRNA levels have a decreased 5 -year survival, which implies that follistatin has important role in the progression of endometrial cancer (https:/ / www.proteinatlas.org) [45].

Angiopoietins are, after VEGF, the second most studied cytokine family with angiogenic properties [46]. Their receptor Tie-2 is essential in the remodeling and maturation of blood and lymphatic vessels. As a receptor for both angiopoietin- 1 and -2 , it has both pro- and anti-angiogenic properties [47,48]. One immunohistochemical study showed that Tie2 expression in endothelial cells tended to be lower in G2 and G3 endometrial adenocarcinoma than in normal endometrium [36]. Correspondingly, our study has revealed significantly lower Tie-2 plasma levels in EC patients.

Leptin is well known for its role in the regulation of energy homeostasis, neuroendocrine function, and metabolism [49]. Furthermore, it also induces endothelial cell proliferation and the expression of metalloproteinases [50]. In our study, EC patients had significantly higher leptin plasma levels; however, they also had significantly higher BMI values.

There are only a few clinical case reports of tumor G-CSF production in gynecologic malignancies. The elevated plasma values were mainly reported in highly advanced nonendometrioid EC with poor prognosis or a large tumor burden [51-53]. In our study, EC patients had lower G-CSF plasma levels; however, the median values of both cancer and control groups remained relatively low compared to the case reports with advanced type 2 EC, evaluated via the commercially available ELISA kit [54].

To compare the diagnostic value of the studied AFs with biomarkers that are in clinical use, we compared the ROC curves for sTie-2, G-CSF, and leptin with those for CA-125 and HE4. CA-125 and HE4 have been extensively studied in ovarian and EC, and their diagnostic and prognostic values in gynecological cancers have been reported [16,55-57]. This comparison revealed that sTie-2, G-CSF, and leptin have similar AUC values as CA-125 and HE4 for the separation of EC and control patients.

To conclude, the results of our study indicate that the plasma levels of different AFs might be involved in the growth of endometrioid EC. The plasma levels of G-CSF, Tie-2, and leptin significantly differ between EC and control patients. The plasma concentrations of these AFs could represent an important additional diagnostic tool for the early detection and characterization of EC and could guide the decision-making regarding the extent of surgery. Further validation studies with larger patient numbers are currently ongoing.

Supplementary Materials: The following are available online at https:/ /www.mdpi.com/2077-038 3/10/4/765/s1, Table S1: Clinicopathological characteristics of the patients with endometrial cancer, Table S2: Patient medication intake within 7 days prior to enrolment, Table S3: Assay Sensitivities (minimum detectable concentrations, $\mathrm{pg} / \mathrm{mL}$ ).

Author Contributions: Conceptualization, T.L.R., Š.S., and L.R.; methodology, T.K. (Tamara Knific) and T.K. (Teja Klančič); resources, T.L.R. and Š.S.; data curation, T.K. (Tamara Knific) and T.K. (Teja Klančič); writing—original draft preparation, L.R.; writing—review and editing, T.L.R. and Š.S.; visualization, L.R.; supervision, T.L.R. and Š.S.; funding acquisition, Š.S. and T.L.R. All authors have read and agreed to the published version of the manuscript.

Funding: This research was funded by the Slovenian Research Agency Grants J3-8212 and J3-2535 to T.L.R and University Medical Centre Ljubljana tertiary project with grant number TP20190155 to Š.S. 
Institutional Review Board Statement: The study was conducted according to the guidelines of the Declaration of Helsinki, and approved by Ethics Committee of the Republic of Slovenia (No. 0120-515/2017/4).

Informed Consent Statement: Written informed consent was obtained from all subjects involved in the study.

Data Availability Statement: The data presented in this study are available on request from the corresponding author. The data are not publicly available due to data privacy restrictions.

Acknowledgments: The authors thank Eva Lasic for editing a draft of this manuscript.

Conflicts of Interest: The authors declare no conflict of interest.

\section{References}

1. Constantine, G.D.; Kessler, G.; Graham, S.; Goldstein, S.R. Increased incidence of endometrial cancer following the women's health initiative: An assessment of risk factors. J. Women's Heal. 2019, 28, 237-243. [CrossRef] [PubMed]

2. Felix, A.S.; Brinton, L.A. Cancer progress and priorities: Uterine cancer. Biomarkers Prev. 2018, 27, 985-994. [CrossRef] [PubMed]

3. Voss, M.A.; Ganesan, R.; Ludeman, L.; McCarthy, K.; Gornall, R.; Schaller, G.; Wei, W.; Sundar, S. Should grade 3 endometrioid endometrial carcinoma be considered a type 2 cancer-A clinical and pathological evaluation. Gynecol. Oncol. 2012, 124, 15-20. [CrossRef]

4. Bokhman, J.V. Two pathogenetic types of endometrial carcinoma. Gynecol. Oncol. 1983, 15, 10-17. [CrossRef]

5. Tesfamariam Sengal, A. Editorial updates in classification and pathogenesis of endometrial cancer. Cronicon $2017,5,115-117$.

6. Murali, R.; Soslow, R.A.; Weigelt, B. Classification of endometrial carcinoma: More than two types. Lancet Oncol. 2014, 15, e268-e278. [CrossRef]

7. Oberndorfer, F.; Moling, S.; Hagelkruys, L.; Grimm, C.; Polterauer, S.; Sturdza, A.; Aust, S.; Reinthaller, A.; Müllauer, L.; Schwameis, R. Risk reclassification of patients with endometrial cancer based on tumor molecular profiling: First real world data. J. Pers. Med. 2021, 11, 48. [CrossRef]

8. Soslow, R.A.; Tornos, C.; Park, K.J.; Malpica, A.; Matias-Guiu, X.; Oliva, E.; Parkash, V.; Carlson, J.; McCluggage, W.G.; Gilks, C.B. Endometrial carcinoma diagnosis. Int. J. Gynecol. Pathol. 2019, 38, S64-S74. [CrossRef] [PubMed]

9. Colombo, N.; Creutzberg, C.L.; Amant, F.; Bosse, T.; González-Martín, A.; Ledermann, J.; Marth, C.; A Nout, R.; Querleu, D.; Mirza, M.R.; et al. ESMO-ESGO-ESTRO consensus conference on endometrial cancer: Diagnosis, treatment and follow-up. J. Gynecol. Cancer 2016, 26, 2-30. [CrossRef]

10. Morice, P.; Leary, A.; Creutzberg, C.; Abu-Rustum, N.; Darai, E. Endometrial cancer. Proc. Lancet 2016, 387, 1094-1108. [CrossRef]

11. Soslow, R. High-grade endometrial carcinomas - strategies for typing. Histopathology 2013, 62, 89-110. [CrossRef] [PubMed]

12. Frumovitz, M.; Singh, D.K.; Meyer, L.; Smith, D.H.; Wertheim, I.; Resnik, E.; Bodurka, D.C. Predictors of final histology in patients with endometrial cancer. Gynecol. Oncol. 2004, 95, 463-468. [CrossRef]

13. Larson, D.M.; Johnson, K.K.; Broste, S.K.; Krawisz, B.R.; Kresl, J.J. Comparison of D\&C and office endometrial biopsy in predicting final histopathologic grade in endometrial cancer. Obstet. Gynecol. 1995, 86, 38-42. [CrossRef]

14. Suh-Burgmann, E.; Hung, Y.Y.; Armstrong, M.A. Complex atypical endometrial hyperplasia: The risk of unrecognized adenocarcinoma and value of preoperative dilation and curettage. Obstet. Gynecol. 2009, 114, 523-529. [CrossRef] [PubMed]

15. Knific, T.; Vouk, K.; Smrkolj, Š.; Prehn, C.; Adamski, J.; Rižner, T.L. Models including plasma levels of sphingomyelins and phosphatidylcholines as diagnostic and prognostic biomarkers of endometrial cancer. J. Steroid Biochem. Mol. Biol. 2018, 178, 312-321. [CrossRef] [PubMed]

16. Kamel, H.F.M.; Al-Amodi, H.S.A.B. Exploitation of Gene Expression and Cancer Biomarkers in Paving the Path to Era of Personalized Medicine. Genom. Proteom. Bioinform. 2017, 15, 220-235. [CrossRef] [PubMed]

17. Nowak-Sliwinska, P.; Alitalo, K.; Allen, E.; Anisimov, A.; Aplin, A.C.; Auerbach, R.; Augustin, H.G.; Bates, D.O.; van Beijnum, J.R.; Bender, R.H.F.; et al. Consensus guidelines for the use and interpretation of angiogenesis assays. Angiogenesis 2018, 21, 425-532. [CrossRef] [PubMed]

18. Carmeliet, P.; Jain, R.K. Angiogenesis in cancer and other diseases. Nat. Cell Biol. 2000, 407, 249-257. [CrossRef]

19. Hillen, F.; Griffioen, A.W. Tumour vascularization: Sprouting angiogenesis and beyond. Cancer Metastasis Rev. 2007, 26, 489-502. [CrossRef]

20. Sherwood, L.M.; Parris, E.E.; Folkman, J. Tumor angiogenesis: Therapeutic implications. N. Engl. J. Med. 1971, 285, 1182-1186. [CrossRef]

21. Ucuzian, A.A.; Gassman, A.A.; East, A.T.; Greisler, H.P. Molecular mediators of angiogenesis. J. Burn Care Res. 2010, 31, 158-175. [CrossRef] [PubMed]

22. Tas, F.; Duranyildiz, D.; Oguz, H.; Camlica, H.; Yasasever, V.; Topuz, E. Circulating serum levels of angiogenic factors and vascular endothelial growth factor receptors 1 and 2 in melanoma patients. Melanoma Res. 2006, 16, 405-411. [CrossRef]

23. Szarvas, T.; Jäger, T.; Droste, F.; Becker, M.; Kovalszky, I.; Romics, I.; Ergun, S.; Rübben, H. Serum levels of angiogenic factors and their prognostic relevance in bladder cancer. Pathol. Oncol. Res. 2008, 15, 193-201. [CrossRef] [PubMed] 
24. Papa, A.; Zaccarelli, E.; Caruso, D.; Vici, P.; Panici, P.B.; Tomao, F. Targeting angiogenesis in endometrial cancer-New agents for tailored treatments. Expert Opin. Investig. Drugs 2015, 25, 31-49. [CrossRef] [PubMed]

25. Kilgore, L.C.; Partridge, E.E.; Alvarez, R.D.; Austin, J.; Shingleton, H.M.; Noojin, F.; Conner, W. Adenocarcinoma of the endometrium: Survival comparisons of patients with and without pelvic node sampling. Gynecol. Oncol. 1995, 56, 29-33. [CrossRef]

26. Todo, Y.; Yamamoto, R.; Minobe, S.; Suzuki, Y.; Takeshi, U.; Nakatani, M.; Aoyagi, Y.; Ohba, Y.; Okamoto, K.; Kato, H. Risk factors for postoperative lower-extremity lymphedema in endometrial cancer survivors who had treatment including lymphadenectomy. Gynecol. Oncol. 2010, 119, 60-64. [CrossRef]

27. Knific, T.; Osredkar, J.; Smrkolj, Š.; Tonin, I.; Vouk, K.; Blejec, A.; Grazio, S.F.; Rižner, T.L. Novel algorithm including CA-125, HE4 and body mass index in the diagnosis of endometrial cancer. Gynecol. Oncol. 2017, 147, 126-132. [CrossRef]

28. Amant, F.; Mirza, M.R.; Koskas, M.; Creutzberg, C.L. Cancer of the corpus uteri. Int. J. Gynecol. Obstet. 2018, 143, 37-50. [CrossRef]

29. Crean-Tate, K.K.; Reizes, O. Leptin regulation of cancer stem cells in breast and gynecologic cancer. Endocrinology 2018, 159, 3069-3080. [CrossRef] [PubMed]

30. Żyła, M.M.; Kostrzewa, M.; Litwińska, E.; Szpakowski, A.; Wilczyński, J.R.; Stetkiewicz, T. The role of angiogenic factors in endometrial cancer. Menopausal Rev. 2014, 13, 122-126. [CrossRef] [PubMed]

31. Berry, K.K.; Varney, M.L.; Dave, B.J.; Bucana, C.D.; Fidler, I.J.; Singh, R.K. Expression of interleukin-8 in human metastatic endometrial carcinoma cells and its regulation by inflammatory cytokines. Int. J. Gynecol. Cancer 2001, 11, 54-60. [CrossRef]

32. Myśliwiec, P.; Pawlak, K.; Kukliński, A.; Kedra, B. Combined perioperative plasma endoglin and VEGF-A assessment in colorectal cancer patients. Folia Histochem. Cytobiol. 2008, 46, 487-492. [CrossRef]

33. Ferrara, N. VEGF as a therapeutic target in cancer. Oncology 2005, 69, 11-16. [CrossRef] [PubMed]

34. Melincovici, C.S.; Boşca, A.B.; Şuşman, S.; Mărginean, M.; Mihu, C.; Istrate, M.; Moldovan, I.M.; Roman, A.L.; Mihu, C.M. Vascular endothelial growth factor (VEGF) - key factor in normal and pathological angiogenesis. Rom. J. Morphol. Embryol. 2018, 59, 455-467. [PubMed]

35. Siveen, K.S.; Prabhu, K.; Krishnankutty, R.; Kuttikrishnan, S.; Tsakou, M.; Alali, F.Q.; Dermime, S.; Mohammad, R.M.; Uddin, S. Vascular endothelial growth factor (VEGF) dignaling in tumour vascularization: Potential and challenges. Curr. Vasc. Pharmacol. 2017, 15, 339-351. [CrossRef] [PubMed]

36. Saito, M.; Sato, Y.; Watanabe, J.; Kuramoto, H.; Kaba, S.; Fukuda, T. Angiogenic factors in normal endometrium and endometrial adenocarcinoma. Pathol. Int. 2007, 57, 140-147. [CrossRef]

37. Moller, B.; Rasmussen, C.; Lindblom, B.; Olovsson, M. Expression of the angiogenic growth factors VEGF, FGF-2, EGF and their receptors in normal human endometrium during the menstrual cycle. Mol. Hum. Repord. 2001, 7, 65-72. [CrossRef] [PubMed]

38. Kamat, A.A.; Merritt, W.M.; Coffey, N.; Lin, Y.G.; Patel, P.R.; Broaddus, R.; Nugent, E.; Han, L.Y.; Landen, C.N.; Spannuth, W.A.; et al. Clinical and biological significance of vascular endothelial growth factor in endometrial cancer. Clin. Cancer Res. 2007, 13, 7487-7495. [CrossRef]

39. Fujimoto, J.; Ichigo, S.; Hirose, R.; Sakaguchi, H.; Tamaya, T. Expressions of vascular endothelial growth factor (VEGF) and its mRNA in uterine endometrial cancers. Cancer Lett. 1998, 134, 15-22. [CrossRef]

40. Shaarawy, M.; El-Sharkawy, S.A. Biomarkers of intrinsic angiogenic and anti-angiogenic activity in patients with endometrial hyperplasia and endometrial cancer. Acta Oncol. 2001, 40, 513-518. [CrossRef]

41. Okon, I.S.; Ding, Y.; Coughlan, K.A.; Wang, Q.; Song, P.; Benbrook, D.M.; Zou, M.H. Aberrant NRP-1 expression serves as predicator of metastatic endometrial and lung cancers. Oncotarget 2015, 7, 7970-7978. [CrossRef] [PubMed]

42. Oplawski, M.; Dziobek, K.; Grabarek, B.; Zmarzły, N.; Dabrus, D.; Januszyk, P.; Brus, R.; Tomala, B.; Boron, D. Expression of NRP-1 and NRP-2 in endometrial cancer. Curr. Pharm. Biotechnol. 2019, 20, 254-260. [CrossRef]

43. Ren, P.; Chen, F.-F.; Liu, H.-Y.; Cui, X.-L.; Sun, Y.; Guan, J.-L.; Liu, Z.-H.; Liu, J.-G.; Wang, Y.-N. High serum levels of follistatin in patients with ovarian cancer. J. Int. Med. Res. 2012, 40, 877-886. [CrossRef] [PubMed]

44. Ciarmela, P.; Florio, P.; Sigurdardottir, M.; Toti, P.; Maguer-Satta, V.; Rimokh, R.; Altomare, A.; Tosi, P.; Petraglia, F. Follistatinrelated gene expression, but not follistatin expression, is decreased in human endometrial adenocarcinoma. Eur. J. Endocrinol. 2004, 151, 251-257. [CrossRef] [PubMed]

45. Uhlén, M.; Björling, E.; Agaton, C.; Szigyarto, C.A.-K.; Amini, B.; Andersen, E.; Andersson, A.-C.; Angelidou, P.; Asplund, A.; Asplund, C.; et al. A human protein atlas for normal and cancer tissues based on antibody proteomics. Mol. Cell. Proteom. 2005, 4, 1920-1932. [CrossRef] [PubMed]

46. Fagiani, E.; Christofori, G. Angiopoietins in angiogenesis. Cancer Lett. 2013, 328, 18-26. [CrossRef] [PubMed]

47. Thomas, M.; Augustin, H.G. The role of the angiopoietins in vascular morphogenesis. Angiogenesis 2009, 12, 125-137. [CrossRef] [PubMed]

48. Martin, V.; Liu, D.; Fueyo, J.; Gomez-Manzano, C. Tie2: A journey from normal angiogenesis to cancer and beyond. Histol. Histopathol. 2008, 23, 773-780. [PubMed]

49. Kelesidis, T.; Kelesidis, I.; Chou, S.; Mantzoros, C.S. Narrative review: The role of leptin in human physiology: Emerging clinical applications. Ann. Intern. Med. 2010, 152, 93. [CrossRef] [PubMed]

50. Park, H.-Y.; Kwon, H.M.; Lim, H.J.; Hong, B.K.; Lee, J.Y.; Park, B.E.; Jang, Y.S.; Cho, S.Y.; Kim, H.-S. Potential role of leptin in angiogenesis: Leptin induces endothelial cell proliferation and expression of matrix metalloproteinases in vivo and in vitro. Exp. Mol. Med. 2001, 33, 95-102. [CrossRef] [PubMed] 
51. Yamamoto, K.; Mabuchi, S.; Yamasaki, M.; Yoshimura, M.; Murata, Y. Grave outcome of granulocyte colony-stimulating factorproducing endometrial cancer: A case report and literature review. J. Obstet. Gynaecol. Res. 2012, 39, 1107-1110. [CrossRef] [PubMed]

52. Mikami, M.; Tanaka, K.; Komiyama, S.; Ishikawa, M.; Hirose, T. Primary serous carcinoma of the peritoneum producing granulocyte colony-stimulating factor. Acta Obstet. Gynecol. Scand. 2005, 84, 820-822. [CrossRef] [PubMed]

53. Granger, J.M.; Kontoyiannis, D.P. Etiology and outcome of extreme leukocytosis in 758 nonhematologic cancer patients. Cancer 2009, 115, 3919-3923. [CrossRef] [PubMed]

54. Clark, L.H.; Moll, S.; Houghton, D.; O'Connor, S.; Soper, J.T. Leukocytosis due to markedly elevated granulocyte-colony stimulating factor levels in a patient with endometrial cancer: Case report and literature review. Gynecol. Oncol. Rep. 2017, 20, 5-8. [CrossRef] [PubMed]

55. Jiang, T.; Huang, L.; Zhang, S. Preoperative serum CA125: A useful marker for surgical management of endometrial cancer. BMC Cancer 2015, 15, 1-8. [CrossRef] [PubMed]

56. Modarres-Gilani, M.; Vaezi, M.; Shariat, M.; Zamani, N.; Nourizadeh, R. The prognostic role of preoperative serum CA125 levels in patients with advanced endometrial carcinoma. Cancer Biomarkers 2017, 20, 135-141. [CrossRef]

57. Romera, A.E.; Guardiola, T.C.; Vielba, M.B.; Torralba, C.D.B.; Martín, P.J.C.; Mainar, L.B. HE 4 tumor marker as a predictive factor for lymphatic metastasis in endometrial cancer. Int. J. Gynecol. Obstet. 2020, 149, 265-268. [CrossRef] 